\title{
ANALYSIS OF GLYCODELIN LEVELS BEFORE AND AFTER HYSTEROSCOPIC POLYPECTOMY IN INFERTILE PATIENTS
}

\author{
${ }^{1}$ Department of Gynecology, Faculty of Medical Sciences, University of Kragujevac, Kragujevac, Serbia \\ ${ }^{2}$ Clinical Hospital Center Zemun, Hospital for Gynecology and Obstretics, Serbia \\ "Authors Marija Sorak and Ana Devic contributed equally to this study
}

\section{ANALIZA NIVOA GLIKODELINA PRE I POSLE HISTEROSKOPSKE POLIPEKTOMIJE KOD INFERTILNIH PACIJENTKINJA

\author{
Marija Šrorak ${ }^{1 *}$ i Ana Dević ${ }^{2 *}$
} \\ ${ }^{1}$ Katedra za ginekologiju, Fakultet medicinskih nauka, Univerzitet u Kragujevcu, Kragujevac, Srbija \\ ${ }^{2}$ Kliničko bolnički centar Zemun, Bolnica za ginekologiju i akušerstvo, Srbija \\ "Autori Marija Šorak i Ana Dević su podjednako učestvovali u izradi ove studije}

\begin{abstract}
Glycodelin (or placental protein 14) is a glycoprotein located in the glandular and thin epithelium of the endometrium. It is considered an important factor in the implantation process, and its traces can be found in elevated concentrations in the uterine flushing obtained at the time of implantation, while in the proliferative phase of the cycle, its levels are low. A certain concentration has been found to inhibit the binding of spermatozoids to the zona pellucida of the oocites therefore, it effects conception. It has a role in angiogenesis and is in high concentrations in the tissues of both benign and malignant gynaecological tumours.

The aim of this study is to analyse and display the glycodelin level changes before and after hysteroscopic polypectomy in infertile patients in the uterine flushing fluid and serum. This survey covers 80 infertile patients, who were divided into two groups. The first group, the experimental group, consisted of 50 infertile patients with endometrial polyps, and a control group of 30 infertile patients without endometrial polyps was also included.

The results primarily indicate the existence of changes in glycodelin levels preoperatively in the flushing and venous blood in infertile patients with endometrial polyps compared with the levels after surgery. In the control group of patients, no significant change in the glycodelin levels was detected in the flushing and venous blood. When comparing these two groups, statistically significant differences in the glycodelin levels in the flushing and venous blood were noted. We conclude that the presence of endometrial polyps in the cavum uteri affects the increase in the glycodelin concentration in the flushing fluid and in the plasma. Increased glycodelin concentrations complicate fertilization and implantation.
\end{abstract}

Keywords: cytokine, glycodelin, endometrial polyp, flushing and serum.

\section{SAŽETAK}

Glikodelin (ili placentni protein 14) je glikoprotein koji se nalazi u glandularnom $i$ površinskom epitelu endometrijuma. Smatra se da je jedan od bitnih faktora u procesu implantacije $i$ nalazi se u povišenim koncentracijama u ispirku uterusa dobijenom u vreme implantacije, dok su u proliferativnoj fazi ciklusa njegove vrednosti niske. U određenoj koncentraciji nadeno je da inhibira vezivanje spermatozoida za zonu pelucidu ovuuma, tako da utiče $i$ na koncepciju. Ima ulogu u angiogenezi, te se nalazi u povišenim koncentracijama u tkivu $i$ benignih $i$ malignih ginekoloških tumora.

Cilj ovog rada je analiza i prikaz promena nivoa glikodelina, pre i posle histeroskopske polipektomije kod infertilnih pacijentkinja, u ispirku uterusa $i$ serumu. Istraživanje obuhvata 80 infertilnih pacijentkinja, koje su podeljene u dve grupe. Prvu grupu, eksperimentalnu, cini 50 infertilnih pacijentkinja sa polipom endometrijuma, a kontrolnu grupu 30 infertilnih pacijentkinja bez polipa endometrijuma.

Dobijeni rezultati prvenstveno ukazuju na postojanje promena nivoa glikodelina preoperativno, i u ispirku $i$ u venskoj krvi, kod infertilnih pacijentkinja sa endometrijalnim polipom u odnosu na nivoe nakon operativnog zahvata. U kontrolnoj grupi pacijentkinja nema značajnih promena nivoa glikodelina u ispirku $i$ venskoj krvi. Poređenjem ove dve grupe prisutne su statistički značajne razlike u nivoima glikodelina i u ispirku i u venskoj krvi. Možemo zaključiti da prisustvo endometrijalnog polipa u kavumu uterusa utiče na porast koncentracije glikodelina, $i$ u ispirku $i$ u plazmi. Povećana koncentracija glikodelina otežava i oplodnju i implantaciju.

Ključne reči: citokin, glikodelin, endometrijalni polip, ispirak $i$ serum. 


\section{INTRODUCTION}

Infertility is a problem that affects approximately 80 million couples worldwide. It is believed that approximately $15 \%$ of the general population is affected by this problem. Endometrial polyps occur when the endometrium is hypertrophic, due to oestrogen stimulation (1). A diagnosis is based on sonographic, hysteroscopic or hysterosonographic findings, when a polyp is spotted in the cavum uteri (2).

Cytokines are a large family of protein molecules that function as a mediator and regulator of cellular communications, in both physiological and pathological conditions (3). Different cells produce a variety of cytokines, which act on the chemotaxis, activation, proliferation and differentiation of other cells. Cells that secrete the highest amounts of cytokines are leukocytes. Glycodelin (or placental protein 14) is a cytokine and is a $28 \mathrm{kDa}$ glycoprotein that contains 180 amino acids (4). Glycodelin is encoded by a single gene that is located in the chromosomal region 9q34; it is derived from the endometrium. It consists of a single (GaINAc $\beta 1-4 G l c N A c)$ oligosaccharide series and is located in the glandular and surface epithelium of the endometrium. Glycodelin is the primary product during the secretion phase of endometrial cells. Maximum levels are produced in the secretory endometrium and early pregnancy decidual. It is produced in the lumen of the endometrial glands and can be detected in circulation. The highest concentration of glycodelin is produced during the secretory phase of the endometrial cycle, while at the early proliferative phase, its concentration is low. There are strong indicators that, in conjunction with other cytokines, glycodelin represents an important factor that facilitates implantation (5). It is found in elevated concentrations in the uterine flushing obtained at the time of implantation. During conception, glycodelin levels remain elevated. Glycodelin has an immunosuppressive effect and probably has a protective role in the preservation of embryos from natural killer (NK) cell destruction. Additionally, it has been found that in certain concentrations, glycodelin inhibits the binding of sperm to the zona pellucida of the oocites therefore, it effects conception. Recently, it has been shown that it plays a role in angiogenesis and is elevated in the tissues of both benign and malignant gynaecological tumours (6).

\section{MATERIAL AND METHODS}

The survey was conducted as a study of 80 infertile patients. The two groups of female patients were compared. The first group of patients, the experimental group, consisted of 50 infertile patients diagnosed with endometrial polyps. The second group was a control group of 30 infertile patients without endometrial polyps. The research was carried out at the Gynaecology and Obstetrics Clinic "National Front" in Belgrade, from May 2012 to November 2013, and in the Center for Molecular Medicine and Test- ing of Stem Cells, Faculty of Medical Sciences, in Kragujevac.

This study was conducted on patients with childbearing potential (aged 20-43 years) who were diagnosed with endometrial polyps as a cause of infertility. The polyp diagnoses were determined by transvaginal ultrasound examinations during the first phase of the cycle, by hysterosonographic examinations, or during an actual hysteroscopy in patients with suspected endometrial polyps, based on anamnesis. In addition to the group who participated in the study, there was a control group of patients of the same age who were treated for infertility did not have endometrial polyps. The patients were evaluated for one month after the intervention in terms of peripheral venous blood sampling, cytokine level determinations, and control ultrasound examinations.

Diagnostic and operative hysteroscopies were performed under general anaesthesia in the operating room with appropriate equipment and instruments. The preoperative preparation included a complete diagnosis and the necessary routine analyses including cervical and vaginal smears, chlamydia, mycoplasma and ureaplasma evaluations, Pap test, ultrasound, blood typing, blood count and biochemical analysis with an anaesthetic examination and surgical treatment approval. Surgical procedures were performed in infertile patients to mid-proliferative phase immediately after menstrual bleeding.

Hysteroscopic examination and intervention-polypectomy are done during the first phase of the menstrual cycle (9). During hysteroscopy, the uterine cavity is viewed at a 30-degree angle, which allows for visualization of both mouths of the fallopian tube, fundus, anterior and posterior wall of the uterus as well as the lateral sides of the uterine cavity (10). At the height of the internal uterine mouth with the hysteroscope, a panoramic image of the uterine cavity is displayed, and the presence of any pathological findings, such as endometrial polyps (which are often observed), submucosal fibroids, septa, and adhesions, can be easily visualized. Polyps are removed with hysteroscopic graspers and hysteroscopic scissors followed by electrocoagulation of their base (11).

To determine the glycodelin (PP14) concentration in the uterus flushing during hysteroscopic polypectomy, the operation sequence was as follows: $10 \mathrm{ml}$ injection of saline into the cavum uteri and immediate aspiration without contamination. Then, the flushing was centrifuged at $2500 \mathrm{rpm}$ for 10 minutes. The supernatant was collected and stored at $-20^{\circ} \mathrm{C}$. The glycodelin concentration was determined with the ELISA method at the Center for Molecular Medicine and Testing of Stem Cells, at the Faculty of Medical Sciences in Kragujevac (15).

To determine the glycodelin (PP14) serum concentration, approximately $5 \mathrm{ml}$ of peripheral venous blood was taken from patients in both groups, before hysteroscopic surgery and one month after surgery. The sample processing methodology is as follows: the blood was collected in a vacutainer with heparin and centrifuged for 
10 minutes at $2500 \mathrm{rpm}$. The supernatant was collected and stored at $-20^{\circ} \mathrm{C}$. Detection and determination of the glycodelin concentration was then determined with the ELISA method (16).

The study inclusion criteria were women with endometrial polyps who were verified as 20-43 years of age and treated for primary or secondary infertility as well as infertile women without endometrial polyps of the same age (16).

Criteria for exclusion from the study for both groups of respondents were the existence of submucosal fibroids, endometriosis, endometrial cancer, uterine anomalies, and patients who had surgery on their uterus and tubes, as well as patients with a previous failed ovulation following stimulation.

Statistical data analysis was based on use of the t-test. As the sample distribution in this study (with a minimum group of 30 patients) was mildly leptokurtic and skewed, for this study, t-tests were successfully implemented, and even for similar mean values of the sample, the t-test provided more accurate results than the Wilconxon MannWhitney test (17).

\section{RESULTS}

We analysed the glycodelin levels in the uterus flushing and venous blood from both test and control group patients (8). The levels of this cytokine were examined before and one month after hysteroscopic polypectomy.

Statistical analysis of the patient groups was based on testing the null hypothesis with t-tests of group differences according to the mean value and variance (7). The groups were significantly different if $\mathrm{p}<0.05$.

Figure 1 shows the glycodelin values in the uterine flushing from patients with endometrial polyps compared with the control group during surgery. It can easily be seen that the glycodelin levels in the uterine flushing were significantly decreased in the control group subjects compared with the experimental group. Using the t-test and analysis of the obtained results, it can be concluded that there was a statistically significant difference $(t=1.992 ; \mathrm{p}=0.0144)$.

Analysis of the venous blood glycodelin levels in the endometrial polyp patients is shown in Figure 2. Notably, the venous blood glycodelin levels that were collected a month after hysteroscopic polypectomy were significantly lower. By applying the t-test, it can be concluded that the groups differ statistically $(\mathrm{t}=2.01 ; \mathrm{p}=0.00017)$.

The venous blood glycodelin values in the endometrial polyp and control group patients before hysteroscopic polypectomy are shown in Figure 3. Applying a t-test leads to the conclusion that the groups differ statistically and that the glycodelin levels were significantly higher in the endometrial polyp patients $(\mathrm{t}=1.996 ; \mathrm{p}=0.0036)$.

Figure 4 provides the venous blood glycodelin values in the control group before and one month after hysteroscopy. By applying the t-test, it can be concluded that the groups did not differ statistically, i.e., the glycodelin levels did not significantly differ in the control group before and after hysteroscopy $(\mathrm{t}=2.048 ; \mathrm{p}=0.851)$.

The venous blood glycodelin values in patients one month after hysteroscopic polypectomy and in the control group one month after hysteroscopy are shown in Figure 5 . These levels were found to not be significantly different using the $t$-test $(\mathrm{t}=2.004 ; \mathrm{p}=0.838)$.

\section{DISCUSSION}

The glycodelin concentrations in the flushing and serum were significantly higher in patients with endometrial polyps in comparison with the control group. A month af-

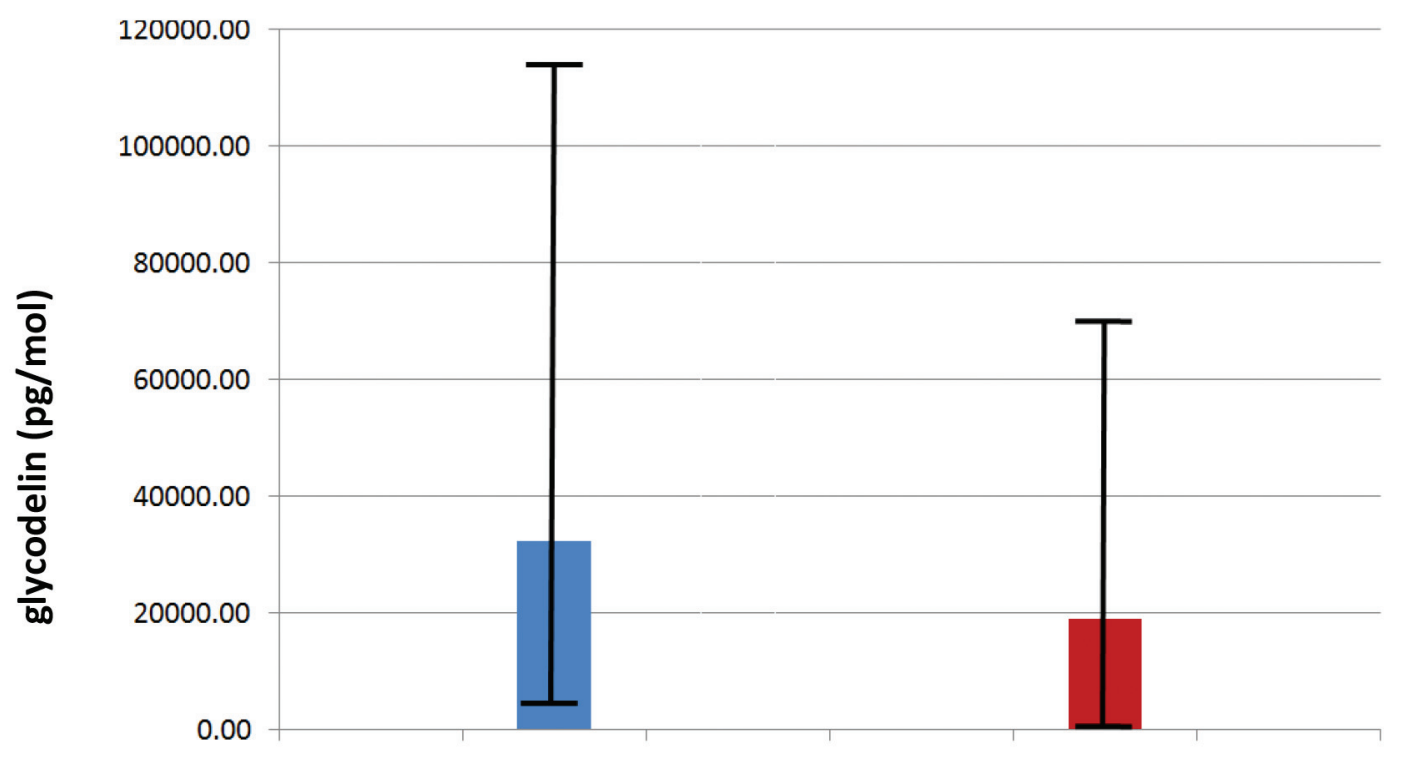

Figure 1. Glycodelin average values in the uterine flushing from patients with endometrial polyps compared with control group patients during hysteroscopy. These are the t-test parameters, the critical average values for accepting the null hypothesis. 


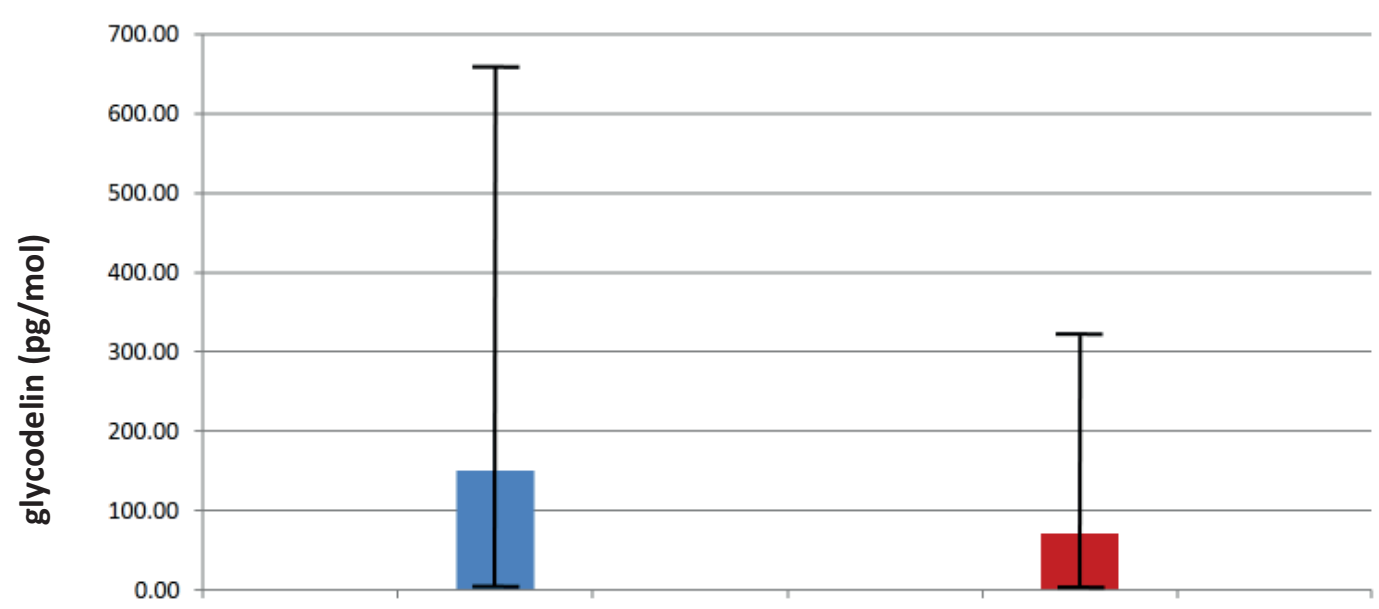

Before

After

Hysteroscopic polypectomy

Figure 2. Venous blood glycodelin average values in patients with endometrial polyps before hysteroscopic polypectomy and one month after surgery.

ter hysteroscopic polypectomy, the serum glycodelin levels were reduced in the experimental group and reached values very similar to the those of the control group. These results were confirmed in most studies that examined glycodelin levels in the uterine flushing and plasma of infertile patients.

Endometrial polyps are common in infertile patients who are preparing for in vitro fertilization, and their presence does not affect pregnancy rates, but there is a higher risk of pregnancy loss in these patients $(18,19)$. Polyps are endometrial tissue growths covered with epithelium.
They have glands, stroma and blood vessels that contribute to increased glycodelin secretion in the cavum uteri $(12,13)$. The common assumption is that glycodelin may "leak" from blood vessels near polyps and dissolve in saline, which is used during hysteroscopy uterine flushing $(14,20)$. Glycodelin levels in uterus flushing fluid are then determined using ELISA measurements, and in most surveys, it was confirmed that the values were significantly higher in uterine flushing with endometrial polyp or submucosal fibroids compared with the control group (21).

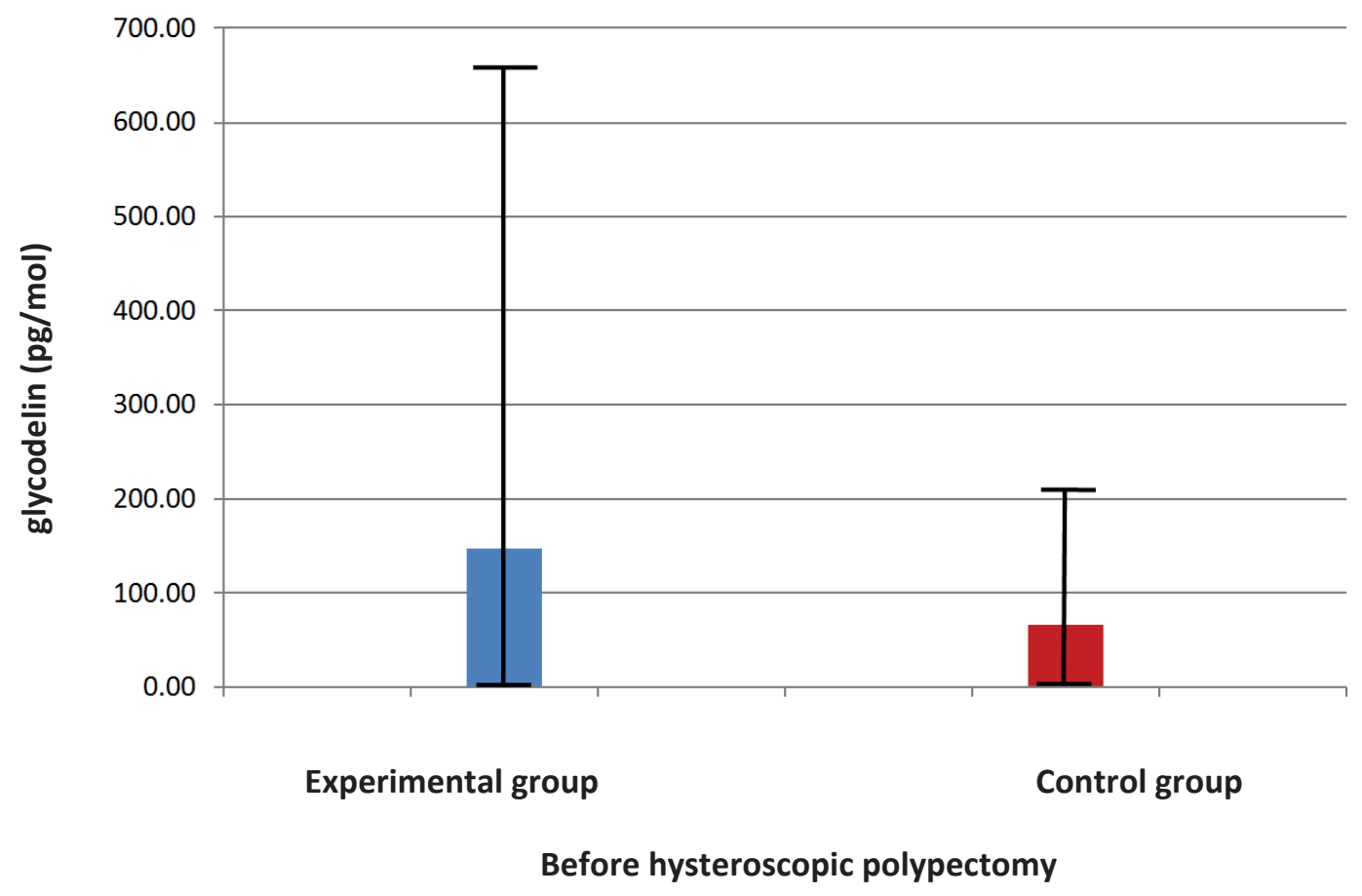

Figure 3. Venous blood glycodelin average values in the endometrial polyp and control group patients before hysteroscopic polypectomy. 


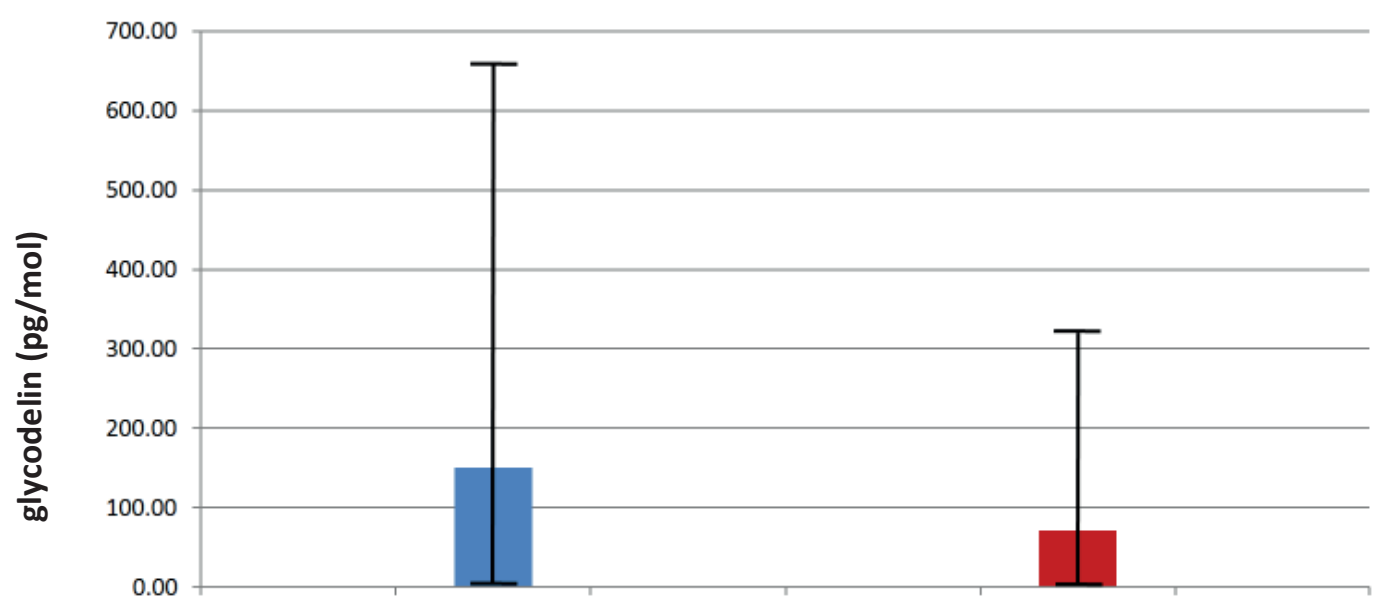

Before

After

Hysteroscopic polypectomy

Figure 4. The venous blood glycodelin average values in the control group patients before hysteroscopy and one month after surgery.

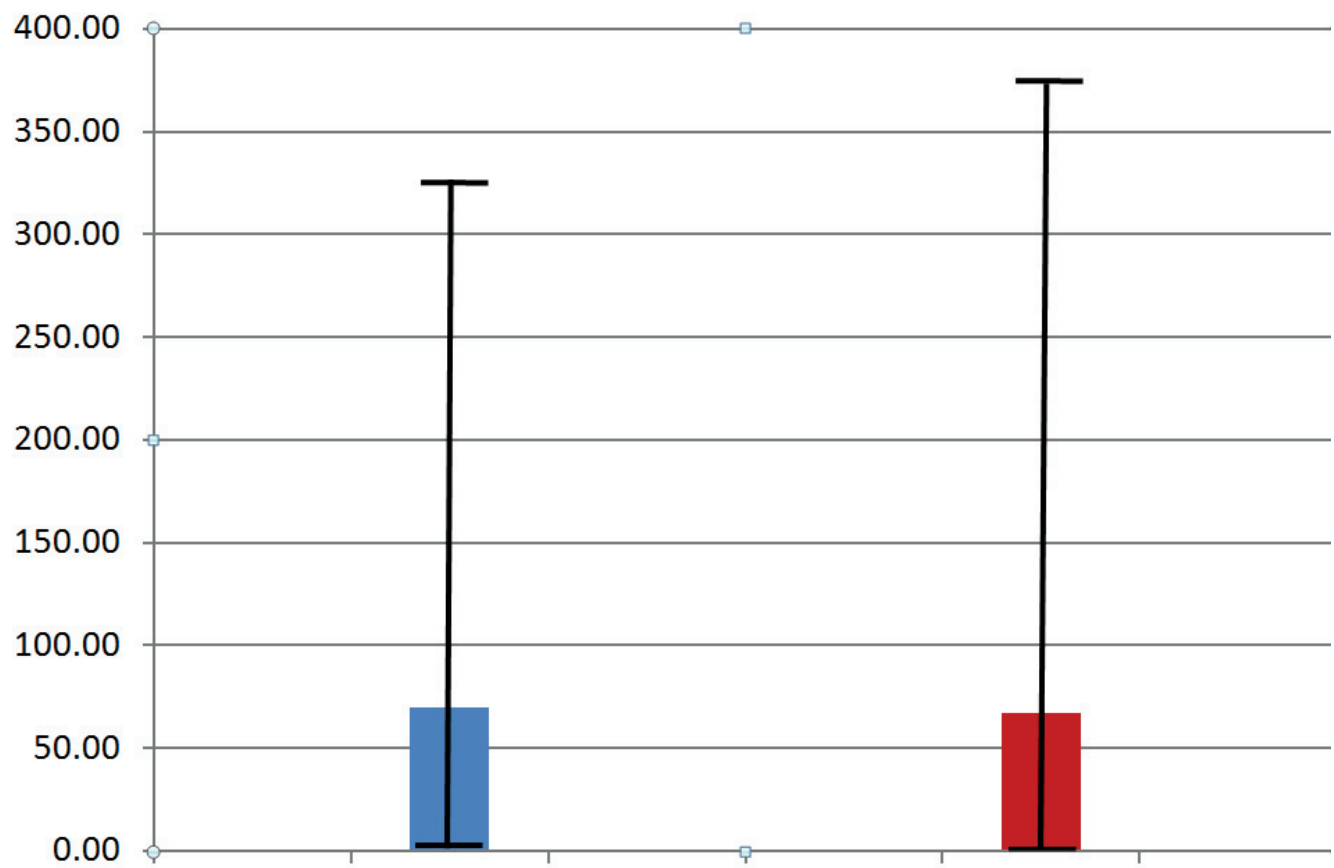

Experimental group

Control group

After hysteroscopic polypectomy

Figure 5. Venous blood glycodelin average values in the endometrial polyp and control group patients one month after surgery. 
Glycodelin contributes to polyp growth by encouraging neovascularization and thus allowing a better flow of the nutrients necessary for polyp growth. It can be detected in the circulation; therefore, in various studies, its concentration in plasma was often determined. In most of these studies, elevated glycodelin levels in the plasma of patients with endometrial polyps was observed compared with control group patients (22).

It has been proven that glycodelin inhibits sperm and oocyte binding as well as NK cell activity (23). Glycodelin values are very low in the period 6 days before and 5 days after ovulation (periovulatory period). Thus, low glycodelin levels allow for fertilization. Then, 6 days after ovulation, glycodelin secretion increases significantly and becomes a key to the formation of a receptive endometrium and suppresses NK cell activity. The results of this study indicate that the glycodelin levels measured during the middle and late proliferative phase of the menstrual cycle were elevated when they should have been at their lowest values, or even absent; however, they significantly affected fertilization and altered endometrial receptivity in patients with endometrial polyps (20).

Changes in glycodelin concentrations are registered in the endometrium, or uterine flushing and are correlated with the values obtained in the serum of the experimental group patients. We conclude that changes in the glycodelin values can be tracked by just specifying the venous blood in patients in whom a hysteroscopic polypectomy was performed and can thus monitor the success of the operational procedures and limit possible polyp recurrences by avoiding administering complicated uterus flushings, which require preoperative preparation and general anaesthesia during a hysteroscopy.

\section{CONCLUSION}

Two groups of infertile patients were analysed, one with endometrial polyps and a second control group that did not have polyps. The glycodelin values in the uterus flushing fluid and in the venous blood before surgery were significantly higher in the patients with endometrial polyps. The uterus flushing fluid and venous blood glycodelin values in the polyp group were significantly decreased one month after surgery. The glycodelin levels in the serum of the control group patients who were detected preoperatively remained similar, even one month after surgery. Additionally, there was no significant difference in the glycodelin levels one month after surgery in a group of patients where the polyps were removed compared with the control group patients.

The results of this study clearly indicate that the glycodelin levels in infertile patients with endometrial polyps were elevated; therefore, we can safely conclude that glycodelin is a cytokine that has a crucial impact on endometrial miles and can significantly disturb homeostasis at the molecular level, thus affecting fertility.

\section{Acknowledgement}

This work was supported by the Faculty of Medical Sciences, University of Kragujevac, Serbia (Grants JP 11/14 (13-2015) "Cytokine levels before and after hysteroscopic polypectomy in infertile patients).

\section{REFERENCES}

1. WethingtonSL, Herzog TJ, Burke WM, Sun X, Lerner JP, Lewin SN, Wright JD. Risk and Predictors of Malignancy in Women with Endometrial Polyps. Annals of Surgical Oncology 2011; 18(13): 381-2.

2. Rackow BW, Jorgensen E, Taylor HS. Endometrial polyps affect uterine receptivity. Fertility and Sterility 2011; 95(8): 2690-2.

3. Richlin SS, Ramachandran S, Shanti A, Murphy AA and Parthasarathy S. Glycodelin levels in uterine flushings and in plasma of patients with leiomyomas and polyps: implications for implantation. Hum Reprod 2002; 17: 2742-7.

4. Bentin-Ley U, Lindhard A, Raven V, Islin H, Sorensen S. Glycodelin in endometrial flushing fluid and endometrial biopsies from infertile women. European Jornal of Obstetrics \& Gynecology and Reproductive Biology 2011; 156: 60-6.

5. M Tabbaa Z, Zheng Y and S Daftary G. KLF11 Epigenetically Regulates Glycodelin-A, a Marker of Endometrial Biology Via Histone-Modifying Chromatin Mechanisms. Reproductive Sciences 2013; 00 (0): 1-10.

6. Inagaki $\mathrm{N}$, Ung L, Otani $\mathrm{T}$, Wilkinson $\mathrm{D}$, Lopata A. Uterine cavity matrix metalloproteinases and cytokines in patients with leiomyoma, adenomyosis or endometrial polyp. Eur J Obstet Gynecol Reprod Biol 2003; 111(2): 197-203.

7. Petrie A, Sabin C. Medical Statistics at a Glance Workbook, John Wiley \& Sons 2012.

8. Popović BV. Handbook of univariate and multivariate data analysis with IBM SPSS, second edition, Journal of Applied Statistics 2015;42 (10).

9. Lasmar BP, Lasmar RB. Endometrial polyp size and polyp hyperplasia. International Journal of Gynecology \& Obstetrics 2013;123 (3): 236-9.

10. Habibaj J, Kosova H, Bilali S, Bilali V, Qama D. Comparison between transvaginal sonography after diagnostic hysteroscopy and laparoscopic chromopertubation for the assessment of tubal patency in infertile women. Journal of Clinical Ultrasound 2012; 40(2):68-73.

11. Nathani F, Clark TJ. Uterine polypectomy in the management of abnormal uterine bleeding: A systematic review. J Minim Invasive Gynecol 2006; 13(4): 260-8.

12. McGurgan P, Taylor LJ, Duffy SR, O’Donovan PJ. Are endometrial polyps from premenopausal women similar to post-menopausal women? An immunohistochemical comparison of endometrial polyps from pre- and post-menopausal women. Maturitas 2006; 20; 54(3): 277-84. 
13. Stamatellos I, Apostolides A, Stamatopoulos P, Bontis J. Pregnancy rates after hysteroscopic polypectomy depending on the size or number of the polyps. Arch Gynecol Obstet 2008; 277(5): 395-9.

14. Li TC, Ling E, Dalton C, Bolton AE and Cooke ID. Concentration of endometrial PP14 in uterine flushings throughout the menstrual cycle in normal, fertile women. Br J Obstet Gynaecol 1993; 100: 460-4.

15. Ben-Nagi J, Miell J, Yazbek J, Holland T, Jurkovic D. The effect of hysteroscopic polypectomy on the concentrations of endometrial implantation factors in uterine flushings. Reproductive BioMedicine Online 2009; 19(5): 737-44.

16. Helmy S, Mavrelos D, Sawyer E, Ben-Nagi J, Koch M, Day A, Jurkovic D. Serum Human Chorionic Gonadotropin ( $\beta$ - hCG) Clearance Curves in Women with Successfully Expectantly Managed Tubal Ectopic Pregnancies: A Retrospective Cohort Study, PLoS ONEPLoS One 2015 2;10(7):e0130598. Epub 2015 Jul 2. , July 2, 2015.

17. Fagerland M.W. T-tests, non-parametric tests, and large studies-a paradox of statistical practice? BMC Medical Research Methodology 201212:78, Fagerland; licensee BioMed Central Ltd. 2012. DOI: 10.1186/14712288-12-78@

18. KW Lam K, CN Chiu P, Cheuk-Lun L, TK Pang R, ON Leung C, Koistinen H, Seppalla M, Chung Ho P and SB
Yeung W. Glycodelin -A Protein Interacts with Siglec-6 Protein to Suppress Trophoblast Invasiveness by Downregulating Extracellular Signal-regulated Kinase (ERK)/cJun Signaling Pathway. J Biol Chem 2011; 286: 37118-27.

19. La Vignera S, Condorelli R, Bellanca S, La Rosa B, Mousavi A, Busa B, O Vicari L, Vicari E. Obesity is associated with a higher level of pro-inflammatory cytokines in follicular fluid of woman undergoing medically assisted procreation (PMA) programs. European Review for medical and Pharmacological Sciences 2011; 15: 267-73.

20. Richlin SS, Ramachandran S, Shanti A, Murphy AA, Parthasarathy S. Glycodelin Levels in Uterine Flushing and in Plasma of Patients with Leiomyomas and Polyps: Implications for Implantation. Human Reproduction 2002; 17 (10):2742-7.

21. Kurman RJ and Mazur MT (eds) Benign diseases of the endometrium. In Blaustein's Pathology of the Female Genital Tract, 4th edn. Springer-Verlag 1994: 394-7.

22. Zhou HM, Ramachandran S, Kim JG, Raynor DB, Rock JA and Parthasarathy S. Implications in the management of pregnancy: II. Low levels of gene expression but enhanced uptake and accumulation of umbilical cord glycodelin. Fertil Steril 2000; 73:843-7.

23. Oehninger S, Coddington CC, Hodgen GD and Seppala M. Factors affecting fertilization: endometrial placental protein 14 reduces the capacity of human spermatozoa to bind to the human zona pellucida. Fertil Steril 1995; 63:377-83. 